African Crop Science Journal by African Crop Science Society is licensed under a Creative Commons Attribution 3.0 Uganda License. Based on a work at www.ajol.info/ and www.bioline.org.br/cs DOI: https://dx.doi.org/10.4314/acsj.v26i4.9

\title{
EFFECT OF INTERMITTENT DROUGHT ON PHENOTYPIC TRAITS OF F5 RIL ANDEAN INTRA-GENE CROSS POPULATION (BRB 191 X SEQ 1027) OF COMMON BEAN
}

\author{
M. NABATEREGGA ${ }^{1,2}$, C. MUKANKUSI ${ }^{2}$, B. RAATZ ${ }^{3}$, R. EDEMA ${ }^{1}$, S. NKALUBO ${ }^{4}$ \\ and B.M.E. ALLADASSI ${ }^{1}$ \\ ${ }^{1}$ College of Agricultural and Environmental Science, Makerere University, P. O. Box7062, Kampala, Uganda \\ ${ }^{2}$ International Centre for Tropical Agriculture (CIAT) / Pan African Bean Research Alliance (PABRA), \\ Kampala, Uganda \\ ${ }^{3}$ International Center for Tropical Agriculture, Cali, Colombia \\ ${ }^{4}$ National Crops Resources Research Institute, Namulonge, P. O. Box 7084, Kampala, Uganda \\ Corresponding author: mnabateregga@gmail.com
}

(Received 26 Februay, 2018; accepted 11 September, 2018)

\begin{abstract}
Drought is a major constraint to common bean (Phaseolus vulgaris L.) production in East Africa, where irrigation for the crop is very uncommon. The objective of this study was to identify drought tolerant lines and phenotypic traits underlying drought tolerance among 128 F5 recombinant inbred lines (RILs), derived from intra gene pool population, between drought tolerant BRB 191 (source of $b c-3$ ) and SEQ 1027. The population was evaluated with eight experimental checks that included BAT 477, CAL 96, DAB 441, DAB 494, and Diacol Calima, NABE 4, SCR 9 and SEQ 1003. A total of 20 phenological, morphological and physiological shoot traits were evaluated, under drought and non-stress conditions, in the field for 2 years (2014 and 2015) at Kawanda in Uganda. New sources of drought tolerance, and previously identified sources of drought tolerance in common bean (BAT 477, DAB 441 and DAB 494), were confirmed based on their superior geometric means and low drought susceptibility. Drought stress in the field significantly affected all measured traits, except harvest index and stem dry weight reduction $(\mathrm{P}<0.001)$. Drought significantly reduced yield, yield components and pod harvest index $(\mathrm{P}<0.01)$. However, chlorophyll content, canopy temperature, stem dry mass reduction, and 100 seed weight remained stable under season by genotype by water regime treatment interactions ( $\mathrm{S} \times \mathrm{G} \times \mathrm{T}$ ). The stability of these traits highlighted their usefulness in selecting for drought tolerance across different environments. Furthermore, pod partitioning index (PPI), harvest index (HI), chlorophyll content and stem dry weight reduction also remained stable under $\mathrm{G}$ x T effects. Significant correlations $(\mathrm{P}<0.001)$ were maintained between HI and PPI with seed yield under drought stress in field conditions, indicating that photosynthate remobilisation increases yield under drought stress conditions.
\end{abstract}

Key Words: Phaseolus vulgaris, photosynthate remobilisation

\section{RÉSUMÉ}

La sécheresse est une contrainte major à la production du haricot commun (Phaseolus vulgaris L.) en Afrique de l'Est, où l'irrigation pour la culture est très rare. L'objectif de cette étude a été d'identifier les lignées tolérantes à la sécheresse et les traits phénotypiques contrôlant la tolérance à la sécheresse parmi les 128 F5 de lignées consanguines recombinantes, dérivées d'une population intra-gène de la région andine, entre la lignée tolérante à 
la sécheresse BRB191 (source du bc-3) et SEQ 1027. La population a été évaluée avec huit contrôles expérimentaux comprenant BAT 477, CAL 96, DAB 441, DAB 494, et Diacol calima, NABE 4, SCR 9 et SEQ 1003. Un total de 20 traits phrénologiques, morphologiques et physiologiques a été évalué, sous les conditions de stress hydrique, dans le champ pour 2 ans (2014 et 2015) à Kwanda en Uganda. De nouvelles sources de tolérance, et des sources de tolérance précédemment identifiées dans le haricot commun (BAT 477, DAB 441 et DAB 494), ont été confirmées sur la base des moyens de supériorité géométriques et de susceptibilité de faible sècheresse. Le stress hydrique dans le champ a significativement affecté tous les traits mesurés, à l'exception de l'indice de récolte et la réduction du poids sec de la tige $(\mathrm{P}<0,001)$. La sécheresse a significativement réduit le rendement, les composantes du rendement et l'indice de la récolte de la gousse $(\mathrm{P}<0.01)$. Toutefois, la température de la canopée, la réduction du poids sec de la tige, et le poids de 100 graines sont restés stables sous le traitement de l'interaction entre la saison $\mathrm{x}$ génotype $\mathrm{x}$ régime d'eau de même que l'interaction entre le génotype $\mathrm{x}$ le traitement $(\mathrm{G} X \mathrm{~T})(\mathrm{P}<0,001)$. La stabilité de ces traits a montré leur utilité dans la sélection pour la tolérance à la sécheresse à travers les différents environnements. De plus, l'indice du partitionnement de la gousse (PPI), l'indice de récolte (HI), la teneur en chlorophylle et la réduction du poids sec de la tige sont restés également stables sous les effets de $\mathrm{G} \mathrm{x}$ T. Des corrélations significatives $(\mathrm{P}<0,001)$ ont été maintenues entre HI et PPI avec le rendement en graine sous le stress hydrique dans les conditions de champ, indiquant la viabilité de la remobilisation de la photosynthate dans l'augmentation du rendement potentiel sous les conditions de stress hydrique.

Mots Clés: Phaseolus vulgaris, remobilisation de la photosynthate

\section{INTRODUCTION}

Common bean (Phaseolus vulgaris L.) is the most important food legume crop for direct consumption in the world (Harvest Plus, 2009). The crop is recognised as the second most important source of dietary protein (Blair et al., 2010), and is particularly suitable for food security due to its short growing cycle (2.5 to 3 months) and adaptability to different cropping systems (Wagara and Kimani, 2007).

Drought is an endemic abiotic constraint in the major producing areas, affecting over $60 \%$ of dry bean production worldwide (Beebe et al., 2013; Lasley, 2013). Bean production in Africa is greatly exposed to the risk of drought, with only $7 \%$ of the bean-growing area receiving adequate rainfall (Sofi et al., 2017). In Uganda, drought has been reported to cause serious dry bean yield losses in nearly all agro-ecological zones (NEMA, 2001; Okonya et al., 2013). Drought stress limits expression of the full genetic potential of crops (Taiz and Zeiger, 2006), causing large effects at all growth stages, especially at grain filling (Rao, 2001).

Several adaptation and mitigation strategies are required to cope with drought stress in crops, however development of droughtadapted cultivars is the most effective control measure for mitigating the effects of drought on common bean yields (Darkwa et al., 2016). Improving tolerance to drought in common bean has been a challenge for a number of reasons; one being the multi-faceted nature of this production constraint as it may be expressed in four different scenarios, namely: (i) low total rainfall throughout the season, (ii) intermittent drought, (iii) terminal drought and (iv) late initiation of rains (Katungi et al., 2011; Beebe et al., 2013). Furthermore, drought hardly occurs in the absence of other stress factors such as pests, diseases and heat stress (Sadras, 2002; Sinclair et al., 2008); which have further made the study of drought tolerance, complex. Identification of key plant traits and mechanisms that contribute to improved drought adaptation may increase the proficiency of breeding programmes in selecting drought tolerant genotypes. However, the process is both labour intensive and time consuming (Beebe et al., 2013; Trapp et al., 2015).

Several studies over the past two decades have identified traits underlying drought tolerance in the common bean. Progress in improving drought tolerance has been more advanced in the Mesoamerican gene pool (majorly small seeded) and intergene populations compared to the Andean gene pool, 
probably because the former are most widely grown around the world and are found in areas where drought stress has been on the increase (Blair et al., 2012). however, the genetics and mechanisms of these traits are still not fully understood (Beebe et al., 2013). This study focused on an Andean derived cross to explore additional diversity for drought resistance alleles, and to analyse the effect of genetic backgrounds on the alleles that have already been identified. The specific objective of the study was to identify key traits underlying drought tolerance in the Andean cross of (BRB 191 x SEQ 1027) RIL population.

\section{MATERIALS AND METHODS}

Plant materials. A F5 recombinant inbred line (RIL) population of 128 lines was evaluated with eight experimental checks at Kawanda during 2014 and 2015. The population was developed from BRB 191 (a source of the bc gene) (Blair et al., 2006) and SEQ 1027 (CIAT, 2008), a large red mottled cultivar with drought tolerance properties developed by CIAT (CIAT, 2008). Both parents are Andean cultivars with bush type growth habits. The BRB/SEQ $\mathrm{F}_{2}$ population was developed at CIAT in Cali, Colombia, and was advanced to F5 generation at Kawanda in Uganda. The F5 population was evaluated with eight checks that included BAT 477, CAL 96, DAB 441, DAB 494, Diacol Calima, NABE 4, SCR 9 and SEQ 1003 (Table 1).

SEQ lines are already widely used in many breeding programmes in Ethiopia, Kenya and Zimbabwe (Beebe, 2012; Simbarashe, 2013). DAB 441 and DAB 494 are part of the advanced drought Andean bean (DAB) nursery developed by CIAT. The DAB nursery has already been phenotyped under different drought conditions in several studies and breeding programmes in Africa (CIAT, 2008). NABE 4 is a red mottled large seeded commercial cultivar in Uganda, resistant to Halo blight, but susceptible to drought (Amongi et al., 2014). SCR 9 is a red seeded cultivar that is tolerant to BCMV and drought (Amongi et al., 2014).

Field evaluation. The field study was carried out in 2014 and 2015, in the off season (planting before the beginning of the rainy season) to target intermittent drought. In 2014, the experiment was carried out from July to October, while in 2015 the experiment was conducted between February and May. This is the short rain season in Uganda. Kawanda, the study site, is located in Uganda at an

TABLE 1. Principal characteristics and merits of bean parental genotypes and checks evaluated at Kawanda in Uganda

\begin{tabular}{|c|c|c|c|c|}
\hline Genotype & Origin & Growth habit & Seed size & Merits \\
\hline BAT 477 & Mesoamerican & III & Small & $\begin{array}{l}\text { Drought tolerant and Resistant to low } \\
\text { soil phosphorous }\end{array}$ \\
\hline CAL 96 & Andean & $\mathrm{I}$ & Large & $\begin{array}{l}\text { Drought susceptible and Tolerant to } \\
\text { angular leaf spot }\end{array}$ \\
\hline DAB 441 & Andean & I & Medium & Drought tolerant \\
\hline DAB 494 & Andean & I & Medium & Drought tolerant \\
\hline Diacol Calima & Andean & I & Large & Drought susceptible \\
\hline NABE 4 & Andean & I & Large & Resistant to Halo blight \\
\hline SCR 9 & Andean & I & Large & Drought tolerant \\
\hline SEQ 1003 & Andean & I & Large & Drought tolerant \\
\hline BRB 191 & Andean & I & Large & Has bc3 gene for BCMV \\
\hline SEQ 1027 & Andean & I & Large & Drought tolerant \\
\hline
\end{tabular}

$\mathrm{I}$ = Determinate habit (Bush); III = Indeterminate bush with weak stem and branches, BCMV = Bean Common Mosaic Virus 
elevation of 1193 masl on latitude $0^{\circ} 24^{\prime} 49^{\prime \prime}$ $\mathrm{N}$ and longitude $32^{\circ} 31^{\prime} 60^{\prime \prime} \mathrm{E}$.

During each experiment, the germplasm was evaluated under field conditions in two water regimes treatment i.e., non-stress (NS) where the plants were irrigated when there was no rain, and drought stress (DS) where there was no irrigation. However, two irrigations of $35 \mathrm{~mm}$ of water using a vehicle water tank were applied in both DS and NS plots, 1 day before planting, and 10 days after planting (DAP) to allow plant germination and initial vegetative growth. The drought intensity was exceptionally high in 2014 that, to avoid complete senescence of the plants, DS treatment received three additional irrigations at 30, 50 and 65 DAP that year. During the first season, the two treatments were in separate fields due to limited land size. However, in 2015, both treatments were run in the same field, separated by a $6 \mathrm{~m}$ buffer zone in order to prevent lateral movement of water between the two regimes.

Plots consisted of two rows of $2.5 \mathrm{~m}$ long, of which one row was used for destructive sampling. The spacing between rows was 80 $\mathrm{cm}$; while between plants in each row was $7.5 \mathrm{~cm}$. Genotypes were replicated three times in each treatment, for each season, in an alpha lattice design comprising of 10 blocks with 14 genotypes per block.

A mixture of fungicides (Ridomil, Dithane M 45 and Amathane) was applied at intervals of 14 days in all plots to reduce disease incidence. Fertiliser (NPK,17:17:17) was applied at the reproductive and flowering stage to address poor soil fertility. Hand weeding was carried out once a month throughout the experiment.

Response variables. Environmental data, including daily rainfall $(\mathrm{mm})$, relative humidity $(\%)$ and temperatures $\left({ }^{\circ} \mathrm{C}\right)$ were obtained from a satellite system by the Uganda National Meteorological Authority (UNMA). To evaluate effects of drought stress on crop growth and yield, 20 traits consisting of phenological, morphological and physiological shoot characteristics were recorded. Phenological traits included days to flowering (DF) and days to physiological maturity (DPM). DF was measured individually for each plot when 50\% of the plants were in a fully flowered state; while DPM was measured individually for each plot when $50 \%$ of the plants had developed fully-matured and dry pods.

Morphological traits measured in this study included growth vigour $(\mathrm{GV})$, growth habit (GH), flower colour (FLCOL), and pods per plant (PDPL) (Corrales and van Schoonhoven, 1987). GV was visually scored at reproductive phase 5, when plants had reached maximum development (Corrales and van Schoonhoven, 1987). The scale use was as follows 1 : excellent, 2: good, 3: intermediate, 4: poor and 5: very poor. GH was measured during the reproductive stage 6 based on visual classification of Corrales and van Schoonhoven, (1987). The evaluation scale was as follows: I: determinate bush; strong and erect stem and branches, II: indeterminate bush habit (erect stems and branches); with guides and ability to climb, III: indeterminate bush habit with weak mainstream and prostrate stem and branches, IV: indeterminate climber habit with weak, long and twisted stem and branches and V: determinate climber. For FLCOL, the prominent colour of freshly opened flowers was recorded at reproductive phase 6, using the CIAT scale of five categories namely: 1: white 2: pink 3: red 4: lavender 5: purple (Hannan, 1983).

For PDPL, the total number of pods was counted at harvest on five randomly selected plants in each plot. Then the average was computed to determine the PDPL for each genotype.

The study also measured a number of physiological traits that were collected and measured destructively or non-destructively. Non-destructive measurements included SPAD Chlorophyll Meter Readings (SCMR) or chlorophyll content and canopy temperature (CT). SPAD (Soil Plant Analysis Development) values were measured once at mid-pod filling (45 DAP), using a non-destructive, hand-held 
chlorophyll meter (SPAD-502 Chlorophyll meter) on a fully expanded young leaf of a randomly chosen plant.

Canopy temperature was also taken at midpod filling on a fully expanded leaf (the same leaf where SCMR was measured) using an infrared thermometer (Telatemp model AG42D, Telatemp, Fullerton, CA, USA). The infrared thermometer was held at $50 \mathrm{~cm}$ from the canopy surface in a $45^{\circ}$ angle to record CT.

Destructive sampling was done at mid-pod filling and harvest to collect data on canopy dry mass components, namely leaf dry weight, stem dry weight and pod dry weight (Polania et al., 2017). At both mid-pod filling and harvest, a row length of $0.5 \mathrm{~m}$ for the first plot was selected; the number of plants counted and the stems cut at the soil surface. Plants were then separated into leaves (without petioles), stems and reproductive structures (pods and flowers). Separated components were then placed in well labelled paper bags and oven-dried at $60^{\circ} \mathrm{C}$ for 48 hours. Samples were then weighed and the dry weights of leaf, pod and stem dry weight recorded for each genotype.

Canopy dry mass was further used to calculate the following indices: Drought intensity index (DII) (Fischer and Maurer, 1978) was used to determine the intensity of drought stress in given environments and was calculated as:

$1-(\mathrm{Xs} / \mathrm{Xi})$

Where:

$\mathrm{Xs}$ is the grand mean yield of all genotypes grown under drought stress, $\mathrm{Xi}$ is the grand mean yield of all genotypes grown under optimum conditions.

Drought susceptibility index (DSI) (Fisher and Maurer, 1978) was used to determine changes in grain yield of a specific genotype under two environments and was calculated as:
$1-\mathrm{Yds} / \mathrm{Yns}) / \mathrm{DII}$

Where:

Yds and Yns are mean yields of a given genotype in drought stress (ds) and no stress (ns) treatments respectively. Geometric mean (GM) was calculated as:

$$
\sqrt{\text { (Ys X Yi) }}
$$

Where:

Ys is yield under the stressed treatment and Yi is yield under the non-stress treatment.

Harvest index (HI) for each genotype was determined as the ratio of seed dry weight at harvest to total shoot dry weight at mid-pod filling. Pod Harvest Index (PHI) was calculated as the percentage of pod dry weight that was due to seed (ratio of seed dry weight at harvest to total pod dry weight at harvest).

Pod wall dry weight proportion (PWBP) for each genotype was calculated as the percentage of pod dry weight due to pod wall (ratio of pod wall dry weight at harvest to total pod dry weight at harvest). Also, pod partitioning index (PPI) for each genotype determined the percentage of total shoot dry weight that is transformed into pods and was calculated as the ratio of pod dry weight at harvest to total shoot dry weight at mid-pod filling.

Stem dry weight reduction (SBR) indicated the percentage of stem dry weight at mid-pod filling that was transformed into pods and was calculated as the ratio of the difference in stem dry weight at mid-pod filling and harvest to stem dry weight at mid-pod filling. Seed yield and 100 seed weight (100SW) for each genotype were also determined at harvest, after the seed was allowed to dry under ambient conditions to moisture content of $14 \%$.

Data analysis. Statistical data analysis was done using GenStat, Discovery Edition Version 4 (Lawes Agricultural Trust, Rothamsted, UK). 
A Restricted maximum likelihood (ReML) mixed model approach was used in GenStat computer package (Release 14.1, PC/Windows 7; VSN International Ltd., 2011) analysis of variance. Water regime treatment and genotype were considered as fixed effects; while replication and block were considered as random effects.

Pearson correlation analysis was done to determine the strength of linear relationship between various plant materials. Similarly, a multiple linear regression analysis was performed; with grain yield as dependent and all other measured traits as independent variables to assess the contribution of these to the RILs response to drought stress. Both correlation and regression analyses were done for each season and for the two water regime treatments using GenStat statistical package.

\section{RESULTS}

Field environmental conditions. The two field trials experienced different levels of intraseasonal droughts during various stages of development (Fig. 1).
The rainfall patterns at Kawanda in both growing seasons were irregular, subjecting the experiment to intermittent drought, rather than a more typical terminal drought. Accordingly, the drought stress was more severe in 2014 than in 2015 as revealed by the total cumulative rainfall per season and the drought intensity index (DII). Total cumulative rainfall received in the field experiments was $178 \mathrm{~mm}$ in 2014 and $325 \mathrm{~mm}$ in 2015. In contrast, DII was 0.775 and 0.415 in 2014 and 2015 respectively. Furthermore, high temperatures might also have augmented the effects of drought in 2014 and 2015. Average temperatures were higher than the optimum range for bean growth $\left(15.6^{\circ}-21.1^{\circ} \mathrm{C}\right)$ in both seasons $\left(22.2^{\circ} \mathrm{C}\right.$ in 2014 and $24.5^{\circ} \mathrm{C}$ in 2015). Although the cumulative rainfall in 2015 was well within the optimum levels, most of the rainfall (65\% in 2015 and $46 \%$ in 2015) was received after yield formation stages and therefore had minimal impact (Fig. 2).

Response of drought related traits to drought stress in 2014 and 2015. Interactions of season by genotype by water

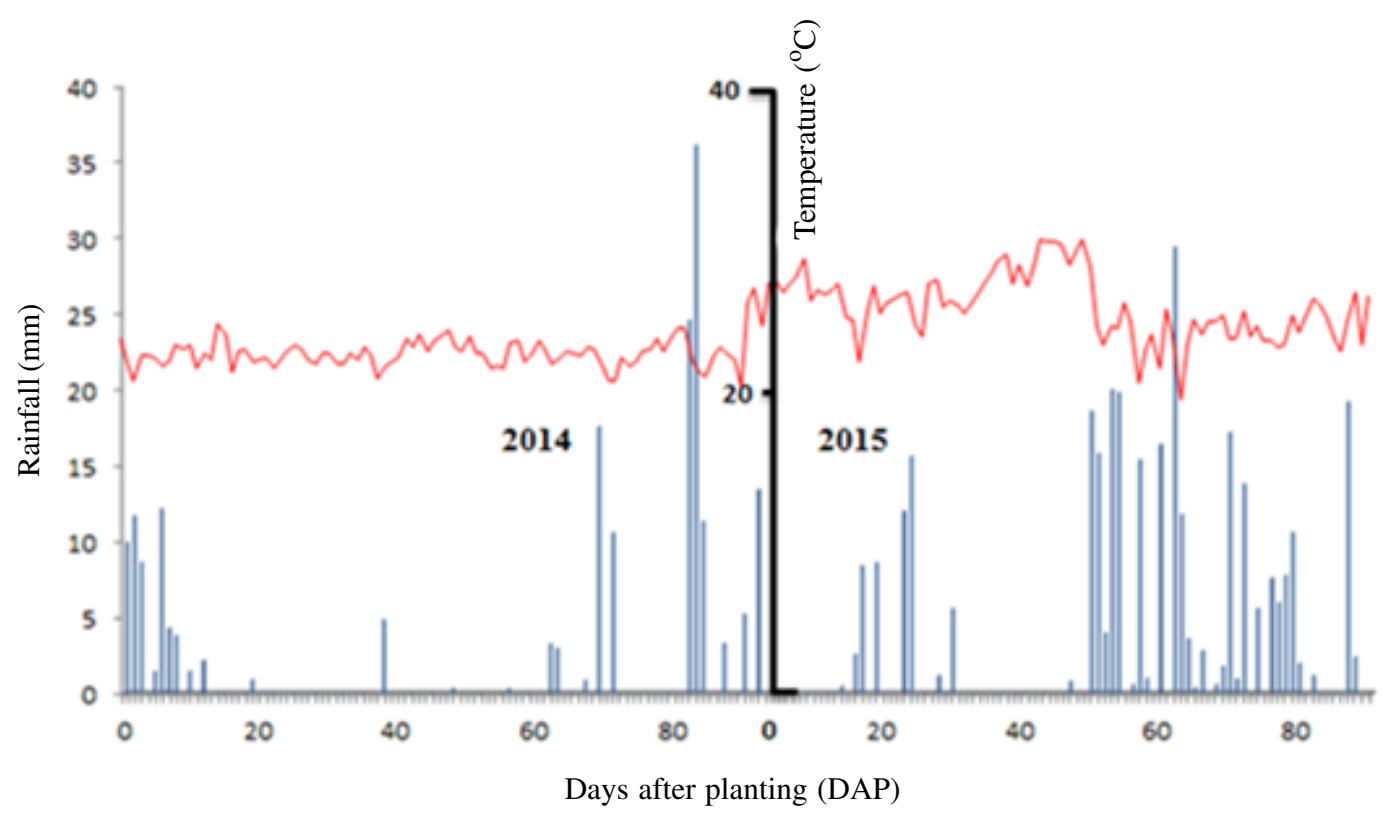

Figure 1. Rainfall (mm) and average temperature $\left({ }^{\circ} \mathrm{C}\right)$ in the off-seasons of 2014 and 2015. 


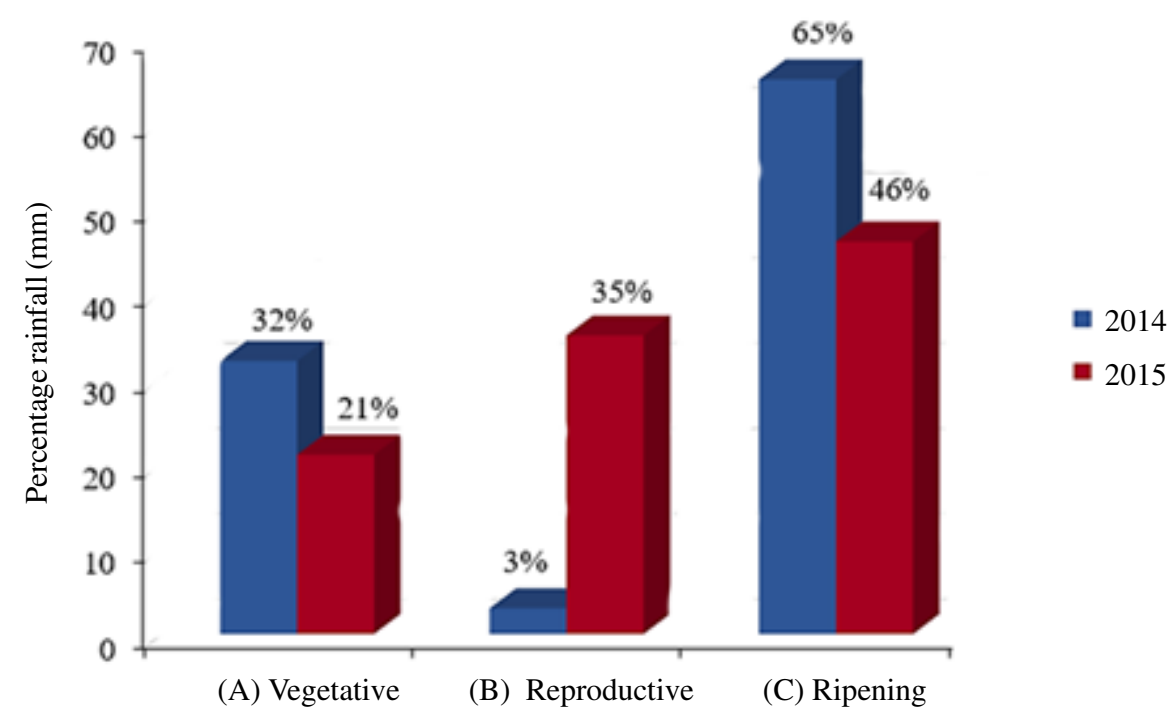

Figure 2. Distributions of percent rainfall $(\mathrm{mm})$ during the growth phases, A: establishment and vegetative (0-30 DAPs), B: reproductive and yield formation (30-60 DAPs) and the ripening phase (60-90 DAPs) in 2014 and 2015 at Kawanda, Uganda.

regime treatment $(\mathrm{S} \times \mathrm{G} \times \mathrm{T})$ significantly affected $(\mathrm{P}<0.05)$ all the traits, except chlorophyll content, canopy temperature, 100 seed weight and stem dry weight reduction (Table 2).

GxT interactions were insignificant for all traits, except for yield, pod harvest index (PHI) and pod wall dry weight proportion (PWBP) $(\mathrm{P}<0.001)$. Genotype by water regime treatment $(\mathrm{G} \times \mathrm{T})$ interactions significantly $(\mathrm{P}<0.05)$ affected eight traits in 2014 and 13 traits in 2015 (Table 3). A number of traits were significantly affected by $\mathrm{G} \times \mathrm{T}$ interactions in 2015 and not in 2014; and vice versa. Partitioning indices were all significantly affected by $\mathrm{G}$ x $\mathrm{T}$ interactions in 2015 . Nevertheless, pod harvest index, pod wall dry weight proportion and stem dry weight reduction were not significantly affected by G x T interactions in 2014.

Seven traits were significantly affected by genotype by irrigation effects in both 2014 and $2015(\mathrm{P}<0.05)$ (Table 3); these included seed yield, harvest index, pod partitioning index, leaf dry weight at MPF, stem dry weight at MPF and pod dry weight at MPF.
The effects of water regime treatment significantly $(\mathrm{P}<0.05)$ affected all traits evaluated in the field, except for harvest index, stem dry weight reduction and pod partitioning index (remained stable in 2014) (Table 2). Drought stress significantly reduced yield, 100 seed weight and number of pods per plant in both 2014 and $2015(\mathrm{P}<0.01)$ (Table 3). Mean yield reductions in the BRB/SEQ were 77.1 and $41.5 \%$ in 2014 and 2015, respectively. The reductions in 100 seed weight due to drought stress were 21.6 and $2.5 \%$ in 2014 and 2015 , respectively; while number of pods per plant was reduced by $55.6 \%$ in 2014 . Harvest index (HI) and pod partitioning index (PPI) were not significantly affected by drought stress, except PPI which remained stable in 2014. Average values for PPI were 92 and $92.2 \%$ in 2014, while it was increased by $14.2 \%$ under drought stress conditions of 2015.

Although all partitioning traits differentiated significantly amongst genotypes $(\mathrm{P}<0.001)$, harvest index was insignificantly different under genotypic effects in 2015 (Table 3).

Analysis of variance showed significant difference between seasons for all the traits, 
TABLE 2. Combined means of squares and levels of significance for 17 traits evaluated at Kawanda in Uganda for two years (2014 and 2015)

\begin{tabular}{|c|c|c|c|c|c|c|c|c|c|}
\hline SOV & Df & Yield & HI & PPI & YPE & SBH & PBH & LB & SBMP \\
\hline Season (S) & 1 & $478703.96^{*}$ & $54407.9^{* *}$ & $42581.13^{\mathrm{ns}}$ & $5.4^{*}$ & $1820.8^{* *}$ & $64704.7^{* *}$ & $104.8^{\mathrm{ns}}$ & $6536.3^{* * *}$ \\
\hline S/Rep & 4 & $267324^{* * *}$ & $2518^{\mathrm{ns}}$ & $5128^{\mathrm{ns}}$ & $0.25^{\mathrm{ns}}$ & $548.4^{* * *}$ & $14403.8^{* * *}$ & $214.4 * *$ & $184.6 * *$ \\
\hline Genotype (G) & 139 & $13013264^{* * *}$ & $757719^{* * *}$ & $1338206.3^{* *}$ & $75.8^{* * * *}$ & $31590.7^{* * *}$ & $342323^{* * *}$ & $27810.1 * * *$ & $44880 * * *$ \\
\hline Treatment (T) & 1 & $31391118^{* * *}$ & $110.9^{\mathrm{ns}}$ & $37528^{*}$ & $0.01^{\mathrm{ns}}$ & $34963.2^{* * *}$ & $1095808^{* * * *}$ & $2308 * * *$ & $30522.5^{* * *}$ \\
\hline $\mathrm{G} \times \mathrm{T}$ & 139 & $4966612.4^{* * *}$ & $614159^{\mathrm{ns}}$ & 1125098.6 & $61.4^{\mathrm{ns}}$ & 10720.4 & $217747^{*}$ & $10501.6^{\mathrm{ns}}$ & $13294.2^{\mathrm{ns}}$ \\
\hline$S \times G$ & 139 & $7660204.8^{* * * *}$ & $581632^{\mathrm{ns}}$ & $1035152.7^{\text {ns }}$ & $58.2^{\text {ns }}$ & $12741.5^{*}$ & $238353^{* *}$ & $13342.8 * * *$ & $17898.7 * * *$ \\
\hline $\mathrm{S} \times \mathrm{T}$ & 1 & $1155338.1^{* * * *}$ & $25319^{* *}$ & $39077.6^{*}$ & $2.5^{* *}$ & 3.7 & $5266^{*}$ & $31422.5 * * *$ & $8123.1^{* * *}$ \\
\hline $\mathrm{S} \times \mathrm{G} \times \mathrm{T}$ & 139 & $4262442.2^{*}$ & $718909^{* *}$ & $1325674.6^{* *}$ & $71.9^{* *}$ & $13353^{*}$ & $241202^{* *}$ & $11041.7 * *$ & $17288.4 * * *$ \\
\hline Error & 1062 & 11413 & 1823 & 3327 & 0.18 & 36.2 & 626.5 & 31.1 & 40.3 \\
\hline LEE & 1080 & 23535.1 & 3696 & 6737.5 & 0.37 & 73.3 & 1272 & 63.5 & 81.2 \\
\hline SOV & Df & PWH & PHI & $100 \mathrm{SW}$ & PWBP & SBR & PBMP & SCMR & $\mathrm{CT}$ \\
\hline Season $(S)$ & 1 & $4830^{* *}$ & $4236.28 * * *$ & $23032.2 * * *$ & $4236.82 * * *$ & $1135^{\text {ns }}$ & $3803112 * * *$ & $207.4^{\text {ns }}$ & $4095.3 *$ \\
\hline S/Rep & 4 & $969.6^{* * *}$ & $124.14 * *$ & $114.1^{\mathrm{ns}}$ & $124.11^{* *}$ & $5165^{\text {ns }}$ & $1525.3^{\mathrm{ns}}$ & $68.4^{* *}$ & $449.7 * *$ \\
\hline Genotype (G) & 139 & $35070.6^{* * * *}$ & $73.72 * * *$ & $297.8 * * *$ & $73.72 * * *$ & $4891 * *$ & $164706^{* *}$ & $13664 * * *$ & $38179.7^{\text {ns }}$ \\
\hline Treatment $(\mathrm{T})$ & 1 & $34841^{* * *}$ & $12929 * * *$ & $12554.4 * * *$ & $12930.1 * * *$ & $13592^{\mathrm{ns}}$ & $1105544 * * *$ & $33071.1 * * *$ & $18334.5^{* * *}$ \\
\hline $\mathrm{G} \times \mathrm{T}$ & 139 & 17377.8 & $51 * * *$ & $131.2^{\mathrm{ns}}$ & $50.98 * * *$ & $4347^{\mathrm{ns}}$ & $142607^{\text {ns }}$ & $5534.7^{\text {ns }}$ & $42682.5^{\text {ns }}$ \\
\hline $\mathrm{S} \times \mathrm{G}$ & 139 & $28601.1^{* * * *}$ & $50.4 * * *$ & $140.6^{\mathrm{ns}}$ & $50.36^{* * * *}$ & $4224^{\text {ns }}$ & $142529.5^{\text {ns }}$ & $6823.8^{* *}$ & $37833.3^{\text {ns }}$ \\
\hline $\mathrm{S} \times \mathrm{T}$ & 1 & $399.2^{\mathrm{ns}}$ & $218.84^{* *}$ & $7762.8^{* * *}$ & $218.72 * *$ & $178751 * * *$ & $242336 * * *$ & $40955.3^{* * *}$ & $49770.1 * * *$ \\
\hline $\mathrm{S} \times \mathrm{G} \times \mathrm{T}$ & 139 & $25945.8^{* *}$ & $52.65 * * *$ & 133.1 & $52.65 * * *$ & 4146 & $167362.6^{* *}$ & $5734.5^{\text {ns }}$ & 41273.7 \\
\hline Error & 1062 & 66.3 & 32.67 & 120.8 & 32.67 & 3713 & 420.4 & 17.1 & 72 \\
\hline LEE & 1080 & 133.5 & - & - & - & - & 862.6 & 34.3 & 291.1 \\
\hline
\end{tabular}

${ }^{*} \mathrm{P}<0.05 ;{ }^{* *} \mathrm{P}<0.01,{ }^{* * *} \mathrm{P}<0.001, \mathrm{~ns}=$ non-significant, $\mathrm{SOV}=$ Source of variation; Rep = Replication, $\mathrm{S}=$ Season $; \mathrm{G}=$ Genotype $\mathrm{T}=$ Water regime treatment LEE $=$ Lattice effective error 
TABLE 3. Effect of drought stress on traits evaluated under field conditions at Kawanda in Uganda in 2014/ 2015

\begin{tabular}{|c|c|c|c|c|c|c|c|c|}
\hline \multirow[t]{2}{*}{ Trait } & \multicolumn{4}{|c|}{2014} & \multicolumn{4}{|c|}{2015} \\
\hline & NS mean & DS mean & $\begin{array}{c}\text { Treatment } \\
\text { effects }\end{array}$ & G x T effects & NS mean & DS mean & $\begin{array}{c}\text { Treatment } \\
\text { effects }\end{array}$ & $\mathrm{G} \times \mathrm{T}$ effects \\
\hline Yield & 294 & 67.1 & $* * *$ & $* * *$ & 371.3 & 217.3 & $* * *$ & * \\
\hline 100 Seed weight & 45.1 & 35.3 & $* * *$ & Ns & 48.2 & 47.01 & ** & Ns \\
\hline Pods per plant & 18 & 8 & $* * *$ & Ns & - & _- & _ & _ \\
\hline Harvest index & 69.2 & 64.2 & Ns & * & 73.2 & 79 & Ns & $*$ \\
\hline Pod harvest index & 75.3 & 69 & $* * *$ & Ns & 77.7 & 72.89 & $* * *$ & $* * *$ \\
\hline Pod partitioning index & 92.2 & 92 & Ns & $*$ & 94.2 & 107.6 & $* * *$ & $* *$ \\
\hline Pod wall dry weight proportion & 24.74 & 31 & $* * *$ & Ns & 22.3 & 27.11 & $* * *$ & $* * *$ \\
\hline Stem dry weight reduction & 13.3 & -13.1 & $* * *$ & Ns & -9 & 5.9 & $* * *$ & $*$ \\
\hline Yield production efficiency & 0.7 & 0.6 & Ns & $*$ & 0.7 & 0.79 & Ns & $*$ \\
\hline SCMR (Chlorophyll content) & 38.6 & 37.8 & * & Ns & 32.6 & 45.86 & $* * *$ & Ns \\
\hline Canopy temperature & 33.6 & 31.5 & $* *$ & Ns & 24.3 & 33 & $* * *$ & $* * *$ \\
\hline Leaf dry weight at MPF & 14.8 & 7.1 & $* * *$ & ** & 9.7 & 14.11 & $* * *$ & Ns \\
\hline Stem dry weight at MPF & 16.6 & 7.5 & $* * *$ & * & 19.5 & 16.6 & $* * *$ & $* *$ \\
\hline Pod dry weight at MPF & 33.1 & 14 & $* * *$ & $*$ & 89.9 & 37.27 & $* * *$ & $*$ \\
\hline Total shoot dry weight at MPF & 64.5 & 28.6 & $* * *$ & * & 119 & 67.8 & $* * *$ & $*$ \\
\hline Stem dry weight at Harvest & 13.4 & 7.1 & $* * *$ & Ns & 19.2 & 12.68 & $* * *$ & $*$ \\
\hline Pod dry weight at Harvest & 55.6 & 22.6 & $* * *$ & Ns & 99.9 & 61.5 & $* * *$ & $* * *$ \\
\hline Pod wall dry weight at Harvest & 13.8 & 6.6 & $* * *$ & Ns & 22.2 & 16.5 & $* * *$ & Ns \\
\hline Days to flowering & 39 & 34 & $* * *$ & $* * *$ & - & - & - & - \\
\hline Days to physiological maturity & 80 & 80.9 & $* * *$ & $*$ & - & - & - & - \\
\hline
\end{tabular}


except PPI, LB, SBR and SCMR suggesting that the overall mean performance of the genotypes was different for the two seasons (Table 2). Seasonal effects contributed more than $50 \%$ to variation (data not shown).

Performance of the F5 RIL (BRB/SEQ) population. Average yield reductions of the $\mathrm{BRB} / \mathrm{SEQ}$ population were 76.6 and $37.4 \%$ in 2014 and 2015, respectively (Table 4). Similarly, the number of pods per plant was reduced by $55.6 \%$ in 2014 . Geometric means (GM) for seed yield ranged from 0 to 358.6 and 33.9 to 491.5 grammes, with the averages of 132.7 and 277.3 grammes in 2014 and 2015, respectively (Table 4). However, average drought susceptibility indices were significantly different between seasons; 0.7 in 2014 versus 0.5 in 2015 .

Seven better performing lines were identified based on their superiority in GM for seed yield, drought susceptibility index (DSI) and percentage reductions (PR) in yield under drought stress; these included RILs 114, 91, 41, 27, 9, 19 and 117 (Table 4). Parental lines (BRB 191 and SEQ 1027) performed better than the population average geometric means in both seasons, with BRB 191 having the highest geometric mean for seed yield in 2014 (Table 4). Furthermore, BRB 191 had an increase in yield under drought stress $(25.7 \%)$ in 2014 unlike the season of 2015 when yield reduced by $43 \%$ (Table 4 ). Recombinant inbred lines 9, 114 and 117 had lower DSI than population average in both seasons. CAL 96 had the lowest seed yield geometric mean and highest percentage reductions in both seasons (Table 4).

Parameter correlations. There was a significant positive correlation between seed yield and 100 seed weight under drought stress treatment in both seasons $(\mathrm{r}=0.35$ and 0.33 in 2014 and 2015, respectively; $\mathrm{P}<0.001$ ) (Table $5)$. In general, highly significant correlations $(\mathrm{r}<0.3, \mathrm{P}<0.001)$ were observed between yield and all partitioning indices (except stem dry weight reduction (SBR) under non-stress conditions in 2014. Inconsistent correlations were observed between seed yield and partitioning indices across the two seasons (2014 and 2015). However, no significant correlations were observed between seed yield and all the partitioning indices under non-stress conditions of 2015 (Table 5).

Specially, harvest index (HI) and pod partitioning index (PPI) had the highest correlations with yield under non-stress conditions in 2014. Furthermore, significant correlations were observed between these traits (HI and PPI) with seed yield under drought stress conditions as well.

Correlations between yield and physiological traits; SCMR and canopy temperature were weak and insignificant. However, there was a highly significant positive correlation between yield and canopy temperature in $2015(\mathrm{r}=0.35, \mathrm{P}<0.001)$ under drought stress conditions (Table 5).

Linear regression analysis. A multiple linear regression analysis was conducted to estimate the effects of selected traits on grain yield for each season and water regime treatment at Kawanda. Regression sums of squares were highly significant $(\mathrm{P}<0.001)$ for both treatments in both seasons (Table 6). Overall, the regression model explained 33.3 and $62 \%$, and 7.5 and $41.3 \%$ under non-stress and drought stress conditions in 2014 and 2015, respectively (Table 6).

Harvest index (HI), 100 seed weight (100SW), leaf dry weight, pod dry weight at harvest and stem dry weight at mid-pod filling contributed significantly $(\mathrm{P}<0.01)$ to the regression model in three environments (Table 7). Leaf dry weight had the highest average contribution to the model with a percentage contribution of 22.8 and $10.7 \%$ in the drought stress trials in 2014 and 2015, respectively (Table 7). 
TABLE 4. Geometric means for seed yield, 100 seed weight, pod harvest index and pod partitioning index, percentage yield reductions and drought susceptibility indices of selected cultivars at Kawanda in Uganda in 2014/ 2015

\begin{tabular}{|c|c|c|c|c|c|c|c|c|c|c|c|c|}
\hline \multirow[t]{2}{*}{ Genotype } & \multicolumn{6}{|c|}{2014} & \multicolumn{6}{|c|}{2015} \\
\hline & Yield $^{\mathrm{GM}}$ & $\begin{array}{r}\mathrm{PR} \\
\text { (yield)\% }\end{array}$ & DSI & $100 \mathrm{SW}^{\mathrm{GN}}$ & $\mathrm{PHI}^{\mathrm{GI}}$ & $\mathrm{PPI}^{\mathrm{GM}}$ & Yield $^{\mathrm{GM}}$ & $\begin{array}{c}\mathrm{PR} \\
\text { (yield)\% }\end{array}$ & DSI & $100 \mathrm{SW}^{\mathrm{G}}$ & $\mathrm{PHI}^{\mathrm{GM}}$ & $\mathrm{PPI}^{\mathrm{GM}}$ \\
\hline SEQ 1027 & 222.5 & 57.9 & 0.46 & 40.9 & 72.4 & 94.3 & 440.3 & 37.3 & -0.49 & 45.9 & 73.2 & 95.9 \\
\hline BRB191 & 358.6 & -25.7 & -0.61 & 48.1 & 75.9 & 65.6 & 302.9 & 56.4 & -0.04 & 59.3 & 76.3 & 82.4 \\
\hline BxS 114 & 252.9 & 49.5 & 0.35 & 45.2 & 70.1 & 97.3 & 372.1 & 19.1 & -0.93 & 54.1 & 78.2 & 154.1 \\
\hline BxS 91 & 211.6 & 56 & 0.44 & 44.5 & 72.3 & 94.5 & 267.5 & -46 & -2.48 & 52.5 & 72.6 & 133.8 \\
\hline BxS 41 & 236 & 61.1 & 0.5 & 41.0 & 73.8 & 101.4 & 332.6 & 7.3 & -1.21 & 50.4 & 77.1 & 81.9 \\
\hline BxS 27 & 187 & 49.6 & 0.35 & 47.1 & 76.6 & 75 & 183.1 & 18.9 & -0.93 & 53.3 & 80.1 & 99.3 \\
\hline BxS 9 & 234.4 & 41.2 & 0.25 & 40.1 & 70.6 & 90.8 & 384.6 & 31.9 & -0.62 & 44.4 & 76.6 & 119.4 \\
\hline BxS 19 & 173.8 & 60.5 & 0.49 & 44.3 & 68.0 & 86.0 & 383.6 & 50.2 & -0.19 & 47.1 & 76.7 & 139.9 \\
\hline BxS 117 & 235.8 & 64.2 & 0.54 & 43.9 & 76.8 & 106.3 & 357.7 & 27.3 & -0.73 & 51.5 & 79.0 & 101.7 \\
\hline Diacol Calima & a $\quad 140.2$ & 62.1 & 0.51 & 40.3 & 77.4 & 85.4 & 197.9 & 78.7 & 0.49 & 47.4 & 78.5 & 100.7 \\
\hline DAB494 & 46 & 84.4 & 0.8 & 34.9 & 72.6 & 53.6 & 153.8 & 80.6 & 0.56 & 41.3 & 78.7 & 79.1 \\
\hline SEQ1003 & 67.1 & 81.2 & 0.76 & 30.9 & 73 & 96.7 & 179.2 & 21.7 & -0.86 & 45.4 & 74.4 & 132.0 \\
\hline SCR9 & 129.9 & 88.5 & 0.85 & 44.4 & 75.4 & 50.7 & 222.2 & -9.6 & -1.61 & 49.7 & 73.5 & 41.4 \\
\hline DAB441 & 88.7 & 73 & 0.65 & 42.9 & 73.8 & 73.4 & 71.8 & 67.1 & 0.21 & 47.3 & 73.1 & 78.5 \\
\hline NABE4 & 141.4 & 79.5 & 0.73 & 40.9 & 77.7 & 105.4 & 113.5 & 56.5 & -0.04 & 50.4 & 77.2 & 100.0 \\
\hline CAL96 & 0 & 100 & 1 & 28.9 & 73.6 & 88.1 & 33.9 & 26.7 & -0.74 & 39.4 & 73.7 & 93.7 \\
\hline BAT477 & 227 & 57.9 & 0.46 & 21.4 & 75.2 & 71.1 & 380 & 61.9 & 0.09 & 28.9 & 70.3 & 94.5 \\
\hline Average & 132.7 & 76.6 & 0.7 & 39.6 & 72.0 & 89.5 & 277.3 & 37.4 & -0.49 & 47.5 & 75.2 & 97.3 \\
\hline Range & $0-358.6$ & $-26-100$ & $-0.61-1$ & $21.4-50.2$ & $63.4-77.7$ & $49.8-180.3$ & $33.9-492$ & $-119-91.4$ & $-4.22-0.8$ & $28.9-60.7$ & $56.4-83.7$ & $35.1-173.7$ \\
\hline
\end{tabular}


TABLE 5. Pearson's correlation coefficients between seed yield and other traits evaluated under both non-stress and drought stress treatments at Kawanda in Uganda

\begin{tabular}{|c|c|c|c|c|}
\hline \multirow[t]{3}{*}{ Other traits } & \multicolumn{4}{|c|}{ Seed yield } \\
\hline & \multicolumn{2}{|c|}{2014} & \multicolumn{2}{|c|}{2015} \\
\hline & NS & DS & NS & DS \\
\hline \multicolumn{5}{|l|}{ Yield components } \\
\hline 100 seed weight & $0.09^{\mathrm{ns}}$ & $0.35^{* * *}$ & $0.13^{* *}$ & $0.33^{* * *}$ \\
\hline Pods per plant & $0.27^{* * * *}$ & $0.10^{\mathrm{ns}}$ & - & - \\
\hline \multicolumn{5}{|l|}{ Partitioning indices } \\
\hline Harvest index & $0.30^{* * * *}$ & $0.12^{* * *}$ & $0.04^{\mathrm{ns}}$ & $0.13^{* *}$ \\
\hline Pod harvest index & $0.20^{* * * *}$ & $0.03^{\text {ns }}$ & $0.09^{\mathrm{ns}}$ & $0.12^{* *}$ \\
\hline Pod partitioning index & $0.25^{* * *}$ & $0.11^{*}$ & $0.02^{\mathrm{ns}}$ & $0.12^{* *}$ \\
\hline Pod wall dry weight proportion & $-0.20^{* * *}$ & $-0.03^{\mathrm{ns}}$ & $-0.09^{\mathrm{ns}}$ & $-0.12^{* *}$ \\
\hline Stem dry weight reduction & -0.07 ns & $-0.04^{\mathrm{ns}}$ & $0.01^{\mathrm{ns}}$ & $0.01^{\mathrm{ns}}$ \\
\hline \multicolumn{5}{|l|}{ Physiological traits } \\
\hline SCMR (Chlorophyll content) & $0.14^{* *}$ & $0.03^{\mathrm{ns}}$ & $0.01^{\mathrm{ns}}$ & $-0.05^{\mathrm{ns}}$ \\
\hline Canopy temperature & $-0.08^{\mathrm{ns}}$ & $-0.09^{\mathrm{ns}}$ & $0.001^{\mathrm{ns}}$ & $0.35^{* * *}$ \\
\hline \multicolumn{5}{|l|}{ Canopy Dry mass components } \\
\hline Leaf dry weight at MPF & $0.11^{*}$ & $0.21^{* * *}$ & $0.08^{\mathrm{ns}}$ & $0.27^{* * *}$ \\
\hline Stem dry weight at MPF & $0.25^{* * * *}$ & $0.19^{* * *}$ & $0.20^{* * *}$ & $0.33^{* * *}$ \\
\hline Pod dry weight at MPF & $0.21^{* * *}$ & $0.25^{* * *}$ & $0.09^{\mathrm{ns}}$ & $0.20^{* * * *}$ \\
\hline Total shoot dry weight at MPF & $0.23^{* * *}$ & $0.25^{* * *}$ & $0.12^{*}$ & $0.29^{* * *}$ \\
\hline Seed dry weight at harvest & $0.53^{* * * *}$ & $0.34^{* * *}$ & $0.18^{* * *}$ & $0.42^{* * *}$ \\
\hline Stem dry weight at harvest & $0.33^{* * * *}$ & $0.22^{* * *}$ & $0.17^{* * *}$ & $0.31^{* * *}$ \\
\hline Pod dry weight at harvest & $0.51^{* * * *}$ & $0.33^{* * * *}$ & $0.17^{* * * *}$ & $0.41^{* * * *}$ \\
\hline Pod wall dry weight at harvest & $0.32^{* * * *}$ & $0.30^{* * *}$ & $0.06^{* * *}$ & $0.31^{* * *}$ \\
\hline
\end{tabular}

${ }^{*} \mathrm{P}<0.05 ;{ }^{* *} \mathrm{P}<0.01,{ }^{* * *} \mathrm{P}<0.001,{ }^{\text {ns }}=$ non-significant, $\mathrm{NS}=$ non stress, $\mathrm{DS}=$ drought stress

TABLE 6. Sums of squares of regression models for drought stress and non-stress conditions at Kawanda in Uganda

\begin{tabular}{|c|c|c|c|c|}
\hline \multirow[t]{2}{*}{ Water regime } & \multicolumn{2}{|c|}{2014} & \multicolumn{2}{|c|}{2015} \\
\hline & s.s & $\%$ explained & s.s & $\%$ explained \\
\hline Non-stress & $1918923 * * *$ & 33.3 & $1001402 * * *$ & 7.5 \\
\hline Drought stress & $11815629 * * *$ & 62.0 & $3520985^{* * *}$ & 41.3 \\
\hline
\end{tabular}

s.s = sums of squares for the regression model, $\%$ explained $=$ percentage contribution by the regression model, ${ }^{*} \mathrm{P}<0.05 ;{ }^{* *} \mathrm{P}<0.01,{ }^{* * *} \mathrm{P}<0.001$ 
TABLE 7. Percentage contribution of selected traits to the total variation of the regression model under nonstress and drought stress conditions at Kawanda in Uganda

\begin{tabular}{lllll}
\hline Trait & \multicolumn{3}{c}{ Contribution to variation (\%) } \\
\cline { 2 - 5 } & \multicolumn{2}{c}{2014} & \multicolumn{2}{c}{2015} \\
\cline { 2 - 5 } & NS & DS & NS & DS \\
\hline Harvest index & $8^{* * *}$ & $2.4^{* * *}$ & $0.1^{\mathrm{ns}}$ & $1.8^{* * *}$ \\
Pod harvest index & $2.4^{* * *}$ & - & - & - \\
Pod partitioning index & $0.2^{\mathrm{ns}}$ & - & $0.9^{\mathrm{ns}}$ & $0.8^{*}$ \\
100 seed weight & - & $9.9^{* * *}$ & $1.8^{* *}$ & $10.9^{* * *}$ \\
Leaf dry weight at MPF & $5.3^{* * *}$ & $22.8^{* * *}$ & - & $10.7^{* * *}$ \\
Stem dry weight at MPF & $0.5^{\mathrm{ns}}$ & $0.6^{* * *}$ & $1.9^{* *}$ & $1.5^{* * *}$ \\
Stem dry weight at harvest & $0.8^{*}$ & $0.4^{* *}$ & $0.4^{\mathrm{ns}}$ & $0.2^{\mathrm{ns}}$ \\
Pod dry weight at MPF & $0.1^{\mathrm{ns}}$ & $0.7^{* * *}$ & - & $0.1^{\mathrm{ns}}$ \\
Pod dry weight at harvest & $0.4^{\mathrm{ns}}$ & $16^{* * * *}$ & $1.9^{* *}$ & $4.8^{* * *}$ \\
\hline
\end{tabular}

$* \mathrm{P}<0.05 ; * * \mathrm{P}<0.01 ; * * * \mathrm{P}<0.001 ;$ ns = not significant, - = not measured, NS = non-stress, DS = drought stress

\section{DISCUSSION}

Field environmental conditions. The kind of drought stress expressed in the field was mainly intermittent drought stress. The amount of rainfall received in both growing seasons (2014 and 2015) at Kawanda was below optimum levels for bean production (350-500 $\mathrm{mm})$. As such, the drought intensity induced in the field was sufficient to evaluate the common bean RIL population for tolerance to drought stress. The population was exposed to a wide range of water deficits that are representative of the conditions bean crops are likely to encounter during growing seasons in Uganda (Mulinde, 2013).

Response of drought related traits to drought stress in 2014 and 2015. Variations in drought induced in the field caused contradictions in the response of evaluated traits to drought related interactions between seasons (Table 3). However, some of the sensitivity of bean traits to environmental stress is not necessarily imposed by the environment, but rather is an active survival response of the plant to stress (Beebe et al., 2008).

This study also helped to identify some key phenotypic traits associated with drought tolerance in Andean bean germplasm. Chlorophyll content, canopy temperature, 100 seed weight and stem dry weight reduction were found to be the most stable traits/ parameters across the highest level of interactions (season by genotype by irrigation regime interactions) (Table 2). Furthermore, these four traits were significantly differentiated amongst genotypes. Genetic diversity is of paramount importance in crop improvement because it determines the selection intensity and effectiveness, and the genetic gain. Thus every breeding programme aims to have a substantial genetic diversity in the breeding population. The significant differences observed among genotypes' means (Table 2) suggest that there was genetic diversity among the RILS. As a result, selection can be made among these RILS for breeding for tolerance to drought stress in Andean Bean. The genetic differentiation and stability of chlorophyll content, canopy temperature, 100 seed weight and stem dry weight reduction across a wide range of interactions proved these characteristics as stable tools for selection for drought tolerance under drought stress (Talebi, 2011; Asfaw et al., 2012). Findings on 100 seed weight in this study are important because the common bean breeding 
programmes have focused on grain size to meet the consumer market, which has preferred larger grains with high seed weight (Carbonell et al., 2010). Therefore, seed weight could be a more efficient and stable tool in selection compared to seed yield (Schneider et al., 1997).

Canopy temperature has been proposed as potential surrogate tools for selecting genotypes with higher WUE in several legumes (Siddique et al., 2001; Condon et al., 2002; Ainsworth and Rogers, 2007; Blum, 2009). According to Guendouz et al. (2012), higher CT leads to flaccidity or looseness of stomata which in turn causes lower carbon fixation efficiency. Consequentially, this results into lower dry matter accumulation and low seed yield. In this study, although canopy temperature was stable under $\mathrm{G} \times \mathrm{T}$, it was non-significantly differentiated among genotypes. This indicated that CT is highly dependent on external environmental factors which could mask genetic variation. Nevertheless, cooler temperatures in the field were associated with increased seed yield as found in other studies (Blum, 2009; Beebe $e t$ al., 2013).

Chlorophyll content was significantly differentiated among genotypes (Table 2). The better performing line 114 and drought tolerant experimental checks BAT 477, DAB 441 and DAB 494 contained higher chlorophyll under drought stress conditions in this study. Similar results have been reported by several authors where values of chlorophyll contents in drought tolerant cultivars were significantly higher than those in drought sensitive genotypes under drought stress (Khayatnezhad, 2011; Alaei, 2011). Accordingly, chlorophyll content could be considered as a reliable indicator in screening germplasm for drought tolerance as other studies have reported (Li et al., 2006; Zaefyzadeh et al., 2009). Nonetheless, selection using a combination of traits like canopy temperature, chlorophyll content, and seed weight would produce more stable drought tolerant lines.
Leaf dry weight at mid pod-filling, pod partitioning index, chlorophyll content and stem dry weight reduction remained significantly stable across seasons (Table 2) despite extreme variations in drought intensity across seasons. Additionally, PPI and HI were also stable under $\mathrm{G} \times \mathrm{T}$ interactions. These results suggested that drought tolerance in this population could been due to the ability of genotypes to remobilise photosynthates into yield during drought stress. Photo-assimilate remobilisation is one of the characteristics indirectly selected during the development of drought resistant cultivars (Rosales-Serna et al., 2004; Miklas et al., 2006). The outstanding performance of stem dry weight reduction and pod partitioning index in this study were important because they confirmed increased reservation of photosynthates as measured by SBR; and the successful transformation of these photosynthates into pod as measured by the PPI. However, some studies have reported increased photosynthate remobilisation without direct effect on yield; a phenomenon known as the 'lazy pod syndrome' (Beebe et al., 2009). Nevertheless, the importance of increased pod partitioning index (PPI) and stem dry weight reduction (SBR) in maintaining yield potential under drought was confirmed as other previous studies had postulated (Klaedtke et al., 2012; Rao et al., 2013; Rao, 2014; Assefa, 2015; Polania et al., 2016). Overall, selection using a combination of drought related traits such as photosynthate remobilisation, seed weight, canopy dry weight, and chlorophyll content will positively impact drought breeding programmes especially in the Andean studies.

Performance of the F5 RIL (BRB/SEQ) population. The impact of drought on yield was evident on number of pods per plant, 100 seed weight and dry matter accumulation (Table 3). It should, however, be noted that reduction in grain yield was greater in 2014 than in 2015 due to the higher drought intensity expressed in 2014. These findings agree with those from other studies where there was 
increased yield under non-stress conditions (Razinger et al., 2010; Darkwa et al., 2016; Polania et al., 2017). As a whole, the BRB 191 $x$ SEQ 1027 RIL population was moderately susceptible to drought stress in 2014 and tolerant in 2015. This was probably because of differences in DSI that resulted from the changes in intensity and duration of drought stress between seasons. Some negative values of DSI were observed (Table 4) indicating higher yield under drought stress compared to non-stress environments; something very uncommon in drought studies of the common bean. Multiple trials in different locations will help ascertain drought susceptibility levels in this population.

According to Porch et al. (2009), duration and intensity of drought stress in common bean significantly determines the level of grain yield reduction. Major reductions in yield and its components due to drought in the common bean have been reported in other studies (Rosales-Serna et al., 2004; Lizana et al., 2006; Emam et al., 2010; Mukeshimana et al., 2014). However, the extent of yield reductions between different studies is controlled by both environmental and genetic factors (Rao and Hodgkin, 2002). According to Farooq et al. (2009), yield reductions in drought studies are inevitable especially when there is a decrease in fresh and dry weights. As observed earlier with yield, reductions in canopy dry weight components were also more pronounced in 2014. Besides, incidence of disease observed in the field such as Angular leaf spot, Anthracnose, Common bacterial blight and Rust could have masked the real potential of drought stress on both canopy dry weight and yield reduction. Diseases mask the expression of the desired drought tolerance traits making it difficult for breeders to identify superior genotypes under drought stress. Therefore, breeding for multiple constraint resistance including disease-drought interaction studies would produce more stable drought resistant genotypes in common bean (Beebe et al., 2008; Makunde, 2013). New sources of drought tolerance were identified among the BRB/SEQ population, which included RILs 9, 91 and 114 (Table 4). Previously identified drought tolerant cultivars such as BAT 477, DAB 441, and DAB 494 were also confirmed based on their outstanding performance (Table 4). Most importantly, BRB 191, the female parent used in this study, was affirmed as a viable source of drought tolerance. It was the highest yielding cultivar in 2014 and 2015.

Parameter correlations. The most stable traits identified in the study namely; chlorophyll content, canopy temperature, 100 seed weight and stem dry weight reduction, also had significant positive correlations with seed yield in different field environments. This further proved them as useful tools for selection for drought tolerance under drought stress (Talebi, 2011; Asfaw et al., 2012). Positive correlations between seed yield and seed weight in both seasons were deemed as important in this study. Negative linkages of SW and seed yield potential in common bean has been a challenge for bean breeders (Beaver and Osorno, 2009); however, results from ours study provide an opportunity for simultaneous selection for these two traits in Andean intragene crosses. Highly significant correlations were observed between seed yield and partitioning.

Linear regression analysis. According to the linear regression model, harvest index and 100 seed weight contributed significantly in three environments (Table 7). Selection using harvest index and 100 seed weight in breeding programmes could indirectly increase yield under both drought stress and non-stress environments for the common bean and other legumes. In the past, harvest index (HI) has proved to be an important trait to breeders in identifying genotypes that are adapted to drought stress through better photosynthate mobilisation (Beebe et al., 2008; Beebe et al., 2013; Rao et al., 2013). 


\section{CONCLUSION}

This study has demonstrated the potential of using better performing RILs in the BRB/SEQ population as sources of drought tolerance to improve Andean cultivars in Uganda. Also, selection for photosynthate remobilisation characterised by HI and PPI would indirectly increase yield potential in Andean genotypes in breeding programmes. Nevertheless, considering the complexity of seed yield under drought stress, selection using a combination of drought related traits would produce more stable and high yielding genotypes. Thus, findings from this study will permit studies to focus on specific genetic regions that control photosynthate acquisition, accumulation and remobilisation for yield improvement under drought stress.

\section{ACKNOWLEDGMENT}

The germplasm of RIL population used in this study was provided by the International Center of Tropical Agriculture (CIAT) and the research was funded by the Tropical Legumes II (TLII) programme through the Pan African Bean Research Alliance (PABRA- CIAT).

\section{REFERENCES}

Ainsworth, E.A. and Rogers, A. 2007. The response of photosynthesis and stomatal conductance to rising [CO2]: mechanisms and environmental interactions. Plant, Cell and Environment 30(3):258-270.

Alaei, Y. 2011. The effect of amino acids on leaf chlorophyll content in bread wheat genotypes under drought stress conditions. Middle-East Journal of Scientific Research 10(1):99-101.

Amongi, W., Nkalubo, S.T., Ochwo, S.M., Gibson, P.T. and Edema, R. 2014. Development of intermittent drought stress tolerant common bean genotypes in Uganda. African Crop Science Journal 22(4):303-315.
Asfaw, A., Blair, M.W. and Struik, P.C. 2012. Multi-environment quantitative trait loci analysis for photosynthate acquisition, accumulation, and remobilization traits in common bean under drought stress. G3: Genes/ Genomes/ Genetics 2(5):579-595.

Assefa, T., Wu, J., Beebe, S.E., Rao, I.M., Marcomin, D. and Claude, R.J. 2015. Improving adaptation to drought stress in small red common bean: Phenotypic differences and predicted genotypic effects on grain yield, yield components and harvest index. Euphytica 203(3):477-489.

Beaver, J.S. and Osorno, J.M. 2009. Achievements and limitations of contemporary common bean breeding using conventional and molecular approaches. Euphytica 168(2):145-175.

Beebe, S.E., Rao, I.M., Blair, M.W and AcostaGallegos, J.A. 2013. Phenotyping common beans for adaptation to drought. Frontiers in Physiology 4:35.

Blair, M.W., Galeano, C.H., Tovar, E., Torres, M.C.M., Castrillón, A.V., Beebe, S.E. and Rao, I.M. 2012. Development of a Mesoamerican intra-genepool genetic map for quantitative trait loci detection in a drought tolerant $\times$ susceptible common bean (Phaseolus vulgaris L.) cross. Molecular Breeding 29(1):71-88.

Blair, M.W., Giraldo, M.C., Buendia, H.F., Tovar, E., Duque, M.C. and Beebe, S.E. 2006. Microsatellite marker diversity in common bean (Phaseolus vulgaris L.). Theoretical and Applied Genetics 113(1):100-109.

Blair, M.W., González, L.F., Kimani, P.M. and Butare, L. 2010. Genetic diversity, intergene pool introgression and nutritional quality of common beans (Phaseolus vulgaris L.) from Central Africa. Theoretical and Applied Genetics 121(2):237-248.

Blum, A. 2009. Effective use of water (EUW) and not water-use efficiency (WUE) is the target of crop yield improvement under 
drought stress. Field Crops Research 112(2):119-123.

Carbonell, S.A., Chiorato, A.F., Gonçalves, J.G., Perina, E.F. and Carvalho, C.R. 2010. Tamanho de grão comercial em cultivares de feijoeiro. Ciência Rural 40:2067-2073.

CIAT. 2008. International Centre for Tropical Agriculture 2008. Annual Report 2008. Outcome line SBA-1. Improved beans for the developing world.

Condon, A.G., Richards, R.A., Rebetzke, G.J. and Farquhar, G.D. 2002. Improving intrinsic water-use efficiency and crop yield. Crop Science 42(1):122-131.

Darkwa, K., Ambachew, D., Mohammed, H., Asfaw, A. and Blair, M.W. 2016. Evaluation of common bean (Phaseolus vulgaris L.) genotypes for drought stress adaptation in Ethiopia. The Crop Journal 4(5):367-376.

Emam, Y., Shekoofa, A., Salehi, F. and Jalali, A.H. 2010. Water stress effects on two common bean cultivars with contrasting growth habits. American-Eurasian Journal of Agricultural and Environmental Sciences 9(5):495-499.

Farooq, M., Wahid, A., Kobayashi, N., Fujita, D. and Basra, S. M. 2009. Plant drought stress: effects, mechanisms and management. In: Sustainable Agriculture pp. 153-188.

Fischer, R.A. and Maurer, R. 1978. Drought resistance in spring wheat cultivars, 1. Grain yield responses. Australian Journal of Agricultural Research 29(4):897-912.

Guendouz, A., Guessoum, S., Maamri, K., Benidir, M. and Hafsi, M. 2012. Canopy temperature efficiency as indicators for drought tolerance in durum wheat (Triticum durum Desf.) in semi-arid conditions. Journal of Agriculture and Sustainability 1(1).

Harvest Plus, Iron-bean, 2009. [(accessed on 26 January 2015)]. Available online: http:// www.harvestplus.org/sites/default/files/ HarvstPlus_Bean_Strategy.pdf.

Katungi, E., Sperling, L., Karanja, D., Farrow, A. and Beebe, S. 2011. Relative importance of common bean attributes and variety demand in the drought areas of Kenya. Journal of Development and Agricultural Economics 3(8):411-422.

Khayatnezhad, M., Gholamin, R., Jamaati, S. and Zabihi, R. 2011. The leaf chlorophyll content and stress resistance relationship considering in corn cultivars (Zea. Mays). Advances in Environmental Biology 118123.

Klaedtke, S.M., Cajiao, C., Grajales, M., Polanía, J., Borrero, G., Guerrero, A. and Léon, J. 2012. Photosynthate remobilization capacity from drought-adapted common bean (Phaseolus vulgaris L.) lines can improve yield potential of interspecific populations within the secondary gene pool. Journal of Plant Breeding and Crop Science 4(4):49-61.

Lasley, A.L. 2013. Evaluation of root traits associated with drought tolerance in dry bean (Phaseolus Vulgaris L.). Michigan State University. Plant Breeding, Genetics and Biotechnology-Crop and Soil Sciences.

Li, R.H., Guo, P.G., Michael, B., Stefania, G., and Salvatore, C. 2006. Evaluation of chlorophyll content and fluorescence parameters as indicators of drought tolerance in barley. Agricultural Sciences in China 5(10):751-757.

Lizana, C., Wentworth, M., Martinez, J.P., Villegas, D., Meneses, R., Murchie, E.H. and Pinto, M. 2006. Differential adaptation of two varieties of common bean to abiotic stress: I. Effects of drought on yield and photosynthesis. Journal of Experimental Botany 57(3):685-697.

Makunde, G. 2013. Quantification of genetic diversity for drought adaptation in a reference collection of common bean (Phaseolus vulgaris L.). University of The Free State, Bloemfontein, South Africa.

Miklas, P.N., Hu, J., Grünwald, N.J. and Larsen, K.M. 2006. Potential application of TRAP (targeted region amplified polymorphism) markers for mapping and 
tagging disease resistance traits in common bean. Crop Science 46(2):910-916.

Mukeshimana, G., Butare, L., Cregan, P.B., Blair, M.W. and Kelly, J.D. 2014. Quantitative trait loci associated with drought tolerance in common bean. Crop Science 54(3):923-938.

Mulinde, C. 2013. An assessment of meteorological drought occurrence and severity in Uganda. Doctoral dissertation, Makerere University, Kampala, Uganda. pp. 196-201

National Environment Management Authority (NEMA). 2001. District population densities and protected areas, NEMA, Kampala, Uganda. http://nile.river awarenesskit.org/English/NRAK/ Resources/Document centrel Uganda SoE 2000.pdf

Okonya, J.S., Syndikus, K. and Kroschel, J. 2013. Farmers' perception of and coping strategies to climate change: evidence from six Agro-ecological zones of Uganda. Journal of Agricultural Science 5(8):252.

Polania, J., Rao, I.M., Cajiao, C., Grajales, M., Rivera, M., Velasquez, F. and Beebe, S.E. 2017. Shoot and root traits contribute to drought resistance in recombinant inbred lines of MD 23-24× SEA 5 of common bean. Frontiers in Plant Science 8:296.

Porch, T.G., Ramirez, V.H., Santana, D. and Harmsen, E.W. 2009. Evaluation of common bean for drought tolerance in Juana Diaz, Puerto Rico. Journal of Agronomy and Crop Science 195(5):328334.

Ramirez-Vallejo, P. and Kelly, J.D. 1998. Traits related to drought resistance in common bean. Euphytica 99(2):127-136.

Rao, I.M. 2001. Role of physiology in improving crop adaptation to abiotic stresses in the tropics: The case of common bean and tropical forages. Handbook of Plant and Crop Physiology, 583-613.

Rao, V.R. and Hodgkin, T. 2002. Genetic diversity and conservation and utilization of plant genetic resources. Plant Cell, Tissue and Organ Culture 68(1):1-19.
Rao, I., Beebe, S., Polania, J., Ricaurte, J., Cajiao, C., Garcia, R. and Rivera, M. 2013. Can tepary bean be a model for improvement of drought resistance in common bean? African Crop Science Journal 21(4):265 - 281.

Rao, I.M. 2014. Advances in improving adaptation of common bean and Brachiaria forage grasses to abiotic stresses in the tropics. In: Handbook of Plant and Crop Physiology. Pessarakli, M. (Ed.). Boca Raton, FL: CRC Press; Taylor and Francis Group). pp. 847-889.

Razinger, J., Drinovec, L., Šuštar-Vozliè, J., Èremo•nik, B., Megliè, V., and Èerenak, A. 2010. Physiological response of common bean (Phaseolus vulgaris L.) to drought stress. Hmeljarski Bilten 17.

Rosales-Serna, R., Kohashi-Shibata, J., Acosta-Gallegos, J.A., Trejo-López, C., Ortiz-Cereceres, J. and Kelly, J.D. 2004. Biomass distribution, maturity acceleration and yield in drought-stressed common bean cultivars. Field Crops Research 85(2):203211.

Sadras, V. 2002. Interaction between rainfall and nitrogen fertilisation of wheat in environments prone to terminal drought: economic and environmental risk analysis. Field Crops Research 77:201-215.

Siddique, K.H.M., Regan, K.., Tennant, D. and Thomson, B.D. 2001. Water use and water use efficiency of cool season grain legumes in low rainfall Mediterranean-type environments. European Journal of Agronomy 15(4):267-280.

Sinclair, T.R., Zwieniecki, M.A. and Holbrook, N.M. 2008. Low leaf hydraulic conductance associated with drought tolerance in soybean. Physiologia Plantarum 132:446-451.

Sofi, P.A., Rehman, K., Ara, A., Mir, S.A. and Dar, S.A. 2017. Improving screening methods to water stress in common bean (Phaseolus vulgaris L.) using new score indices based on productivity and resilience. International Journal of Current 
Microbiology and Applied Sciences 6(7):967-981.

Taiz, L. and Zeiger, E. 2006. Water and plant cells. Plant Physiology, 4th edn. Sinauer Associates Inc, 672.

Talebi, R. 2011. Evaluation of chlorophyll content and canopy temperature as indicators for drought tolerance in durum wheat (Triticum durum Desf.). Australian Journal of Basic and Applied Sciences 5(11):1457-1462.

Terán, H. and Singh, S.P. 2002. Selection for drought resistance in early generations of common bean populations. Canadian Journal of Plant Science 82(3):491-497.
Trapp, J.J., Urrea, C.A., Cregan, P.B. and Miklas, P.N. 2015. Quantitative trait loci for yield under multiple stress and drought conditions in a dry bean population. Crop Science 55(4):1596-1607.

Wagara, I.N. and Kimani, P.M. 2007. Resistance of nutrient-rich bean varieties to major biotic constraints in Kenya. African Crop Science Conference Proceedings 8:2087-2090.

Zaefyzadeh, M., Quliyev, R.A., Babayeva, S.M. and Abbasov, M.A. 2009. The effect of the interaction between genotypes and drought stress on the superoxide dismutase and chlorophyll content in durum wheat landraces. Turkish Journal of Biology 33(1):1-7. 